\section{Basal Medium with Modified Nitrogen Source and other Factors Influence the Rooting of Banana}

\author{
Yuanli Wu, ${ }^{1}$ Ganjun Yi, Hu Yang, Birong Zhou, and Jiwu Zeng \\ Pomology Research Institute of Guangdong Academy of Agricultural Sciences, \\ Wushan, Tianhe District, Guangzhou, 510640, Guangdong Province, P. R. China
}

Additional index words. micropropagation, Musa, nitrate, orthogonal design

\begin{abstract}
MS is the most commonly used basal medium for the micropropagation of banana (Musa spp.), in which inorganic $\mathrm{N}$ source consists of $\mathrm{NH}_{4}^{+}-\mathrm{N}$ and $\mathrm{NO}_{3}^{-}-\mathrm{N}$, and $\mathrm{NH}_{4}^{+}: \mathrm{NO}_{3}^{-}=1: 2$. In the present study, basal medium for rooting culture was modified by supplying $\mathrm{NO}_{3}^{-}-\mathrm{N}$ as the sole $\mathrm{N}$ source at the concentration of 17.80 to $19.78 \mathrm{mmol} \cdot \mathrm{L}^{-1}$. Not only was the percentage of qualified plantlets higher than that of MS or $1 / 2 \mathrm{MS}$, but the cost for medium preparation (per liter) was about \$0.6 lower than that of MS based on local retail price, for the concentration of $N$ decreased from about $60 \mathrm{mmol} \cdot \mathrm{L}^{-1}$ to nearly $20 \mathrm{mmol} \cdot \mathrm{L}^{-1}$. The effects of four factors: sucrose $\left(25\right.$ to $\left.35 \mathrm{~g} \cdot \mathrm{L}^{-1}\right)$, NAA $\left(0.2\right.$ to $\left.1.0 \mathrm{mg} \cdot \mathrm{L}^{-1}\right)$, IBA $\left(0.2\right.$ to $\left.1.0 \mathrm{mg} \cdot \mathrm{L}^{-1}\right)$, and basal medium with modified $\mathrm{N}$ source on the percentage of qualified plantlets were studied by using orthogonal design. The variance analysis of data showed that all the four factors significantly affected the process of rooting culture. Among them, sucrose was the most important factor, followed by revised basal medium, IBA, and NAA. The optimal medium for rooting culture was BM II supplemented with $30 \mathrm{~g} \cdot \mathrm{L}^{-1}$ sucrose, $0.5 \mathrm{mg} \cdot \mathrm{L}^{-1} \mathrm{NAA}$, and $0.5 \mathrm{mg} \cdot \mathrm{L}^{-1}$ IBA. During the following acclimation phase, $>90 \%$ of plantlets survived. Chemical name used: 6-benzylaminopurine (BA); indole-3-butyric acid (IBA); $\alpha$-naphthaleneacetic acid (NAA).
\end{abstract}

Since Ma and Shii first reported the shoot-tip culture of banana (Musa spp.) and the regeneration of plantlets through the formation of adventitious buds $(1972,1974)$, the in vitro multiplication of banana by shoot-tip culture or meristem culture has been successfully established (Bower and Fraser, 1982; Dore Swamy et al., 1983; Cronauer and Krikorian, 1984; Wong, 1986; Acuña Chinchila, 1993; Dhumale et al., 1997; Bekheet and Saker, 1999; Arinaitwe et al., 2000). Compared with the conventional method of propagation, suckers produced at the base of each mother plant, micropropagated plantlets have many advantages: 1) The rate of proliferation is high and there are no season limits for the production of planting material; 2) The field performance of plantlets is characterized by growing fast and regularly, and the fact that banana fruit can be harvested almost at the same time makes field management easier (Hwang et al., 1984; Vuylsteke and Ortiz, 1996); and 3) Micropropagation procedure including virus eliminating treatment (Berg and Bustamante, 1974) and virus-free status confirmation by molecular indexing methods (Samuel et al., 1999) is helpful to control virus disease effectively.

So far, the most commonly used basal medium for the micropropagation of banana is MS (Murashige and Skoog, 1962), in which inorganic nitrogen source consists of $\mathrm{NH}_{4}^{+}-\mathrm{N}$ and $\mathrm{NO}_{3}^{-}-\mathrm{N}$, and $\mathrm{NH}_{4}^{+}: \mathrm{NO}_{3}^{-}=1: 2$. On the other hand, reports comparing the effects of different

Received for publication 20 July 2004. Accepted for publication 11 Sept. 2004.

${ }^{1}$ To whom reprint requests should be sent; e-mail 4eand1p@21cn.com.
$0.3 \mathrm{mg} \cdot \mathrm{L}^{-1} \mathrm{NAA}, 30 \mathrm{~g} \cdot \mathrm{L}^{-1}$ sucrose and $6 \mathrm{~g} \cdot \mathrm{L}^{-1}$ agar; and the $\mathrm{pH}$ adjusted to 5.8. The cultures were maintained at $25 \pm 2{ }^{\circ} \mathrm{C}$ under a 16 -h photoperiod of $50 \mu \mathrm{mol} \cdot \mathrm{m}^{-2} \cdot \mathrm{s}^{-1}$ from cool-white fluorescent lamps.

Root differentiation. The basal media of rooting culture included MS (control treatment) and those with modified nitrogen source: basal medium $(\mathrm{BM}) 1=1600 \mathrm{mg} \cdot \mathrm{L}^{-1} \mathrm{KNO}_{3}$, no $\mathrm{NH}_{4} \mathrm{NO}_{3}, 440 \mathrm{mg} \cdot \mathrm{L}^{-1} \mathrm{CaCl}_{2} \cdot 2 \mathrm{H}_{2} \mathrm{O}$, the rest of components were the same as MS; $\mathrm{BM} 2=$ $1800 \mathrm{mg} \cdot \mathrm{L}^{-1} \mathrm{KNO}_{3}$, the rest of components were the same as BM1; BM3 $=1900 \mathrm{mg} \cdot \mathrm{L}^{-1}$ $\mathrm{KNO}_{3}$, the rest of components were the same as $\mathrm{BM} 1$; $\mathrm{BM} 4=2000 \mathrm{mg} \cdot \mathrm{L}^{-1} \mathrm{KNO}_{3}$, the rest of components were the same as BM1; BM5 $=2100 \mathrm{mg} \cdot \mathrm{L}^{-1} \mathrm{KNO}_{3}$, the rest of components were the same as BM1; BM6 $=2600 \mathrm{mg} \cdot \mathrm{L}^{-1}$ $\mathrm{KNO}_{3}$, the rest of components were the same as $\mathrm{BM} 1 ; \mathrm{BMI}=1213 \mathrm{mg} \cdot \mathrm{L}^{-1} \mathrm{KNO}_{3}$, no $\mathrm{NH}_{4} \mathrm{NO}_{3}$, $706 \mathrm{mg} \cdot \mathrm{L}^{-1} \mathrm{Ca}\left(\mathrm{NO}_{3}\right)_{2} \bullet 4 \mathrm{H}_{2} \mathrm{O}$, no $\mathrm{CaCl}_{2} \cdot 2 \mathrm{H}_{2} \mathrm{O}$, the rest of components were the same as MS; BM II $=1314 \mathrm{mg} \cdot \mathrm{L}^{-1} \mathrm{KNO}_{3}$, the rest of components were the same as BM I; BM III $=1415 \mathrm{mg} \cdot \mathrm{L}^{-1} \mathrm{KNO}_{3}$, the rest of components were the same as BM I.

All basal media were supplemented with 0.2 to $1.0 \mathrm{mg} \cdot \mathrm{L}^{-1} \mathrm{NAA}, 0.2-1.0 \mathrm{mg} \cdot \mathrm{L}^{-1} \mathrm{IBA}, 2$ $\mathrm{g} \cdot \mathrm{L}^{-1}$ activated charcoal, 25 to $35 \mathrm{~g} \cdot \mathrm{L}^{-1}$ sucrose and $6 \mathrm{~g} \cdot \mathrm{L}^{-1}$ agar; and the $\mathrm{pH}$ adjusted to 5.8. The cultures maintained at the same condition. The culture vessels were polypropylene bags $(12.5 \times 14 \mathrm{~cm})$ rather than glass bottles $(6 \times$ $9.5 \mathrm{~cm})$ that had been used at previous stage. Each treatment included 150 to 200 plantlets and was repeated three times.

Orthogonal design for rooting culture. Factors that affected the process of in vitro rooting were evaluated individually in the preliminary experiments. On the basis of initial result obtained, four main factors (sucrose, NAA, IBA, and basal medium with modified nitrogen source) and their three different levels were determined respectively. The orthogonal table of $\mathrm{L}_{9}\left(3^{4}\right)$ was selected for studying the effects of four factors on the percentage of qualified plantlets (Table 1). Nine treatments were arranged according to the design and each treatment was repeated three times (Table 4).

Measurement and observation of rooted plantlets. The rooted plantlets were measured when adventitious buds had been inoculated onto rooting culture medium for 30 days according to following morphological standards (Lin et al., 2004).

1) Diameter of pseudostem: measuring the diameter of pseudostem where $2 \mathrm{~cm}$ away from the base of pseudostem (including the part growing roots), those $\geq 0.3 \mathrm{~cm}$, light green in color were marked as qualified.

2) Height of pseudostem: measuring the dis-

Table 1. The design form of the orthogonal test $\mathrm{L}_{9}\left(3^{4}\right)$.

\begin{tabular}{lcccc}
\hline & \multicolumn{3}{c}{ Factor } \\
\cline { 2 - 5 } Levels & $\begin{array}{c}\text { A Sucrose } \\
\left(\mathrm{g} \cdot \mathrm{L}^{-1}\right)\end{array}$ & $\begin{array}{c}\text { B NAA } \\
\left(\mathrm{mg} \cdot \mathrm{L}^{-1}\right)\end{array}$ & $\begin{array}{c}\text { C IBA } \\
\left(\mathrm{mg} \cdot \mathrm{L}^{-1}\right)\end{array}$ & $\begin{array}{c}\text { D Basal medium } \\
(\mathrm{BM})\end{array}$ \\
\hline 1 & 25 & 0.2 & 0.2 & I \\
2 & 30 & 0.5 & 0.5 & II \\
3 & 35 & 1.0 & 1.0 & III \\
\hline
\end{tabular}


Table 2. Effect of inorganic nitrogen form on the percentage of qualified plantlets.

\begin{tabular}{lcccc}
\hline \multirow{2}{*}{$\begin{array}{l}\text { Basal medium } \\
(\mathrm{BM})^{\mathrm{z}}\end{array}$} & \multicolumn{2}{c}{$\begin{array}{c}\text { Inorganic } \mathrm{N} \\
\left(\mathrm{m} \mathrm{mol} \cdot \mathrm{L}^{-1}\right)\end{array}$} & $\begin{array}{c}\text { No. of } \\
\text { investigated } \\
\text { plantlets }\end{array}$ & $\begin{array}{c}\text { Qualified } \\
\text { plantlets } \\
(\%)^{\mathrm{z}}\end{array}$ \\
\cline { 2 - 5 } $\mathrm{MS}$ & 39.41 & 20.62 & 440 & $61.1 \mathrm{bc}$ \\
$1 / 2 \mathrm{MS}$ & 19.71 & 10.31 & 546 & $57.9 \mathrm{c}$ \\
1 & 15.83 & --- & 462 & $61.5 \mathrm{~b}$ \\
2 & 17.80 & --- & 349 & $72.2 \mathrm{a}$ \\
3 & 18.79 & --- & 517 & $72.8 \mathrm{a}$ \\
4 & 19.78 & --- & 538 & $70.3 \mathrm{a}$ \\
5 & 20.77 & --- & 464 & $64.1 \mathrm{~b}$ \\
6 & 25.72 & --- & 509 & $31.1 \mathrm{~d}$ \\
\hline
\end{tabular}

${ }^{\mathrm{a}}$ Basal media were all supplemented with $0.2 \mathrm{mg} \cdot \mathrm{L}^{-1} \mathrm{NAA}, 0.5 \mathrm{mg} \cdot \mathrm{L}^{-1} \mathrm{IBA}, 25 \mathrm{~g} \cdot \mathrm{L}^{-1}$ sucrose.

${ }^{b}$ Values followed by different letters were significantly different according to LSD test $(p=0.05)$.

Table 3. Effect of the type of calcium on the percentage of qualified plantlets.

\begin{tabular}{|c|c|c|c|c|c|}
\hline $\begin{array}{l}\text { Basal } \\
\text { medium }(\mathrm{BM})^{2}\end{array}$ & $\begin{array}{l}\text { Type of } \\
\text { calcium salt }\end{array}$ & $\begin{array}{l}\text { Total }\left[\mathrm{NO}_{3}^{-}\right] \\
\left(\mathrm{mmol} \cdot \mathrm{L}^{-1}\right)\end{array}$ & $\begin{array}{l}\text { Total }\left[\mathrm{Ca}^{2+}\right] \\
\left(\mathrm{mmol} \cdot \mathrm{L}^{-1}\right)\end{array}$ & $\begin{array}{l}\text { No. of investigated } \\
\text { plantlets }\end{array}$ & $\begin{array}{l}\text { Qualified } \\
(\%)^{\mathrm{y}}\end{array}$ \\
\hline III & $\mathrm{Ca}\left(\mathrm{NO}_{3}\right)_{2} \cdot 4 \mathrm{H}_{2} \mathrm{O}$ & 19.98 & 2.99 & 523 & $81.1 \mathrm{a}$ \\
\hline 4 & $\mathrm{CaCl} \cdot 2 \mathrm{H}_{2} \mathrm{O}$ & 19.78 & 2.99 & 538 & $70.3 \mathrm{~b}$ \\
\hline
\end{tabular}

${ }^{2}$ Basal media were both supplemented with $0.2 \mathrm{mg} \cdot \mathrm{L}^{-1} \mathrm{NAA}, 0.5 \mathrm{mg} \cdot \mathrm{L}^{-1} \mathrm{IBA}, 25 \mathrm{~g} \cdot \mathrm{L}^{-1}$ sucrose

${ }^{y}$ Values followed by different letters were significantly different according to LSD test $(p=0.05)$

tance from the base of pseudostem (including the part growing roots) to the crossing point of the newest spreading leaf and pseudostem, those $\geq 4 \mathrm{~cm}$, grow normally and no variation were marked as qualified.

3) Number of leaves spreading naturally: measuring the width of leaf which has leaf stalk at the middle of leaf, recording the number of leaves which are more than or equal to $0.8 \mathrm{~cm}$ in width, those $\geq 1$, deep green in color, grow normally and no variation were marked as qualified.

4) Root system: measuring the length of white roots, recording the number of roots which are more than or equal to $2 \mathrm{~cm}$ in length, those $\geq 3$, and plantlets with profuse root system were marked as qualified.

The percentage of qualified plantlets $(\%)=$ the number of rooted plantlets that meet four morphological standards mentioned above/the total number of rooted plantlets (not including those contaminated by fungi or bacteria) $\times 100 \%$. The data collected from all treatments were arcsine transformed for statistical analysis.

\section{Results and Discussion}

Effect of inorganic nitrogen form on the percentage of qualified plantlets. At rooting stage culture, $1 / 2 \mathrm{MS}$ is a commonly used basal medium besides MS. As shown in Table 2 , although the concentration of $\mathrm{N}$ is half decreased, the ratio of $\mathrm{NH}_{4}^{+}: \mathrm{NO}_{3}^{-}$unchanged and the percentage of qualified plantlets was close to that of $\mathrm{MS}$. When supplying $\mathrm{NO}_{3}^{-}-\mathrm{N}$ as the sole nitrogen source, the growth of rooted plantlets could be significantly improved in a narrow range of concentration (17.80 to 19.78 $\left.\mathrm{mmol} \cdot \mathrm{L}^{-1}\right)$. The percentage decreased when the concentration of $\mathrm{NO}_{3}^{-}$higher or lower than this range. On the other hand, although 1/2 MS and BM4 were almost equally supplied with $\mathrm{NO}_{3}^{-}-\mathrm{N}$, the percentage were $57.9 \%$ and $70.3 \%$ respectively. It seemed that the difference between them was attributed to the existence of $\mathrm{NH}_{4}{ }^{+} \mathrm{N}$.

For most corps, the biomass of plants which applied with mixture nitrogen source are higher than those supplied with $\mathrm{NH}_{4}^{+}-\mathrm{N}$ or $\mathrm{NO}_{3}^{-}-\mathrm{N}$ as the sole nitrogen source. This phenomenon has been called the combination effect of $\mathrm{NH}_{4}^{+}-\mathrm{N}$ and $\mathrm{NO}_{3}^{-}-\mathrm{N}$ by some authors (Abbès et al., 1995). So the reason why the revised medium with $\mathrm{NO}_{3}^{-}-\mathrm{N}$ as the sole nitrogen source could improve the growth of rooted plantlets deserves further study. On the other hand, the adjustment of inorganic nitrogen source in the micropropagation of banana has not been previously reported.
Effect of calcium salt form on the percentage of qualified plantlets. When $\mathrm{CaCl}_{2} \cdot 2 \mathrm{H}_{2} \mathrm{O}$ in $\mathrm{BM} 4$ which was one of the basal media with the highest percentage of qualified plantlets shown in Table 2, was substituted by $\mathrm{Ca}\left(\mathrm{NO}_{3}\right)_{2} \cdot 4 \mathrm{H}_{2} \mathrm{O}$, and the total $\left[\mathrm{NO}_{3}^{-}\right]$and $\left[\mathrm{Ca}^{2+}\right]$ were unchanged at the same time, the percentage can be improved significantly (Table 3 ). It has already verified that $\mathrm{CaCl}_{2}$ was one of the factors that affected the $\mathrm{pH}$ value of MS during the process of autoclaving (Wang etal., 1997). On the other hand, supplying $\mathrm{Ca}\left(\mathrm{NO}_{3}\right)_{2} \bullet 4 \mathrm{H}_{2} \mathrm{O}$ instead of $\mathrm{CaCl}_{2} \cdot 2 \mathrm{H}_{2} \mathrm{O}$ decreased the concentration of $\mathrm{K}$ indirectly, while some authors suggested that MS should be enriched with $\mathrm{P}$ and $\mathrm{K}$ in order to optimize the growth and development of in vitro cultured plantlets (Marchal et al., 1988). Another significant observation was that the substitution also deferred the darkening of root system.

Orthogonal experiment in rooting culture. The results of extreme deviation indicated that the factor that most influenced the results was sucrose, followed by revised basal medium, IBA and NAA. The results of calculation also showed that the optimal combination of rooting culture medium was $\mathrm{A}_{2} \mathrm{~B}_{2} \mathrm{C}_{2} \mathrm{D}_{2}$ : $\mathrm{BM}$ II supplemented with $30 \mathrm{~g} \cdot \mathrm{L}^{-1}$ sucrose, $0.5 \mathrm{mg} \cdot \mathrm{L}^{-1}$ NAA, $0.5 \mathrm{mg} \cdot \mathrm{L}^{-1}$ IBA(Table 4$)$. This combination was not included in 9 combinations of the orthogonal experiment. In the following verification test, although the percentage of qualified plantlets from combination $\mathrm{A}_{2} \mathrm{~B}_{2} \mathrm{C}_{2} \mathrm{D}_{2}$ was slightly higher than those from combination 6 , which had highest percentage in Table 4, the difference between them was not significant. One of the explanations was that the present study was focused on the in vitro rooting from micropropagated shoots, but rooting stage is closely relative to its previous process: the formation and proliferation of adventitious buds. From this viewpoint, the concentration of growth regulators in rooting culture medium can be varied with those in proliferation stage and the times of subculture.

The results of analysis of variance of the percentage of qualified plantlets among the four selected factors were presented in Table 5. The percentage of qualified plantlets was highly significantly $(p<0.01)$ influenced by sucrose, revised basal medium, IBA and NAA.

In recent years, the commercial production of banana plantlets is developing mainly

Table 4. Results of orthogonal experiment in rooting culture and analysis.

\begin{tabular}{|c|c|c|c|c|c|c|c|}
\hline \multirow{3}{*}{$\begin{array}{l}\text { Combination } \\
\text { no. }\end{array}$} & \multicolumn{4}{|c|}{ Factors and their codes } & & & \\
\hline & \multirow{2}{*}{$\begin{array}{c}\text { A Sucrose } \\
\left(\mathrm{g} \cdot \mathrm{L}^{-1}\right)\end{array}$} & \multirow{2}{*}{$\begin{array}{l}\text { B NAA } \\
\left(\mathrm{mg} \cdot \mathrm{L}^{-1}\right)\end{array}$} & \multirow{2}{*}{$\begin{array}{c}\text { C IBA } \\
\left(\mathrm{mg} \cdot \mathrm{L}^{-1}\right)\end{array}$} & \multirow{2}{*}{$\begin{array}{c}\text { D Basal medium } \\
(\mathrm{BM})\end{array}$} & \multicolumn{3}{|c|}{ The percentage of qualified plantlets (\%) } \\
\hline & & & & & Replication 1 & Replication 2 & Replication 3 \\
\hline 1 & 25 & 0.2 & 0.2 & $\mathrm{I}$ & 63.9 & 53.2 & 55.3 \\
\hline 2 & 25 & 0.5 & 0.5 & II & 80.3 & 75.1 & 76.9 \\
\hline 3 & 25 & 1.0 & 1.0 & III & 60.4 & 63.3 & 65.8 \\
\hline 4 & 30 & 0.2 & 0.5 & III & 71.0 & 80.0 & 81.5 \\
\hline 5 & 30 & 0.5 & 1.0 & I & 69.7 & 65.0 & 66.5 \\
\hline 6 & 30 & 1.0 & 0.2 & II & 84.1 & 81.6 & 83.1 \\
\hline 7 & 35 & 0.2 & 1.0 & II & 53.0 & 54.5 & 55.4 \\
\hline 8 & 35 & 0.5 & 0.2 & III & 70.2 & 68.8 & 69.7 \\
\hline 9 & 35 & 1.0 & 0.5 & I & 54.8 & 57.9 & 58.8 \\
\hline $\mathrm{K}_{1}$ & 490.85 & 475.72 & 514.32 & 460.26 & & & \\
\hline $\mathrm{K}_{2}^{1}$ & 547.17 & 519.50 & 517.73 & 524.22 & & & \\
\hline $\mathrm{K}_{3}^{2}$ & 459.31 & 502.11 & 465.28 & 512.85 & & & \\
\hline Range & 29.29 & 14.59 & 17.48 & 21.32 & & & \\
\hline
\end{tabular}


Table 5. Result of one-way analysis of variance (ANOVA).

\begin{tabular}{lccccc}
\hline Sources of variance & Sum of squares & df & Mean square & F value & $F_{0.01}$ \\
\hline A) Sucrose & 440.226 & 2 & 220.113 & $57.218^{*}$ & 6.23 \\
B) NAA & 107.983 & 2 & 53.992 & $14.035^{*}$ & \\
C) IBA & 191.391 & 2 & 95.696 & $24.876^{*}$ & \\
D) Basal medium & 258.736 & 2 & 129.368 & $33.629^{*}$ & \\
Error & 69.244 & 16 & 4.328 & & \\
\hline
\end{tabular}

"Significantly different at $p<0.01$ among A, B, C, and D.

towards the goals of improving quality and reducing production cost at the same time (Alvard et al., 1993; Vinh et al., 1997; Matsumoto and Brandão, 2002). When supplied with proper concentration of sucrose and growth regulators (NAA, IBA), modified basal medium with $\mathrm{NO}_{3}^{-}-\mathrm{N}$ as the sole nitrogen source at the concentration of 17.80 to 19.78 $\mathrm{mmol} \cdot \mathrm{L}^{-1}$ could significantly improve the quality of rooted plantlets. Not only was the percentage of qualified plantlets higher than that of MS or $1 / 2 \mathrm{MS}$, but the cost for mediumpreparation (per liter) was about $\$ 0.6$ lower than that of MS based on local retail price, for the concentration of $\mathrm{N}$ decreased from about $60 \mathrm{~m} \mathrm{~mol} \cdot \mathrm{L}^{-1}$ to nearly $20 \mathrm{~m} \mathrm{~mol} \cdot \mathrm{L}^{-1}$. During the following acclimation phase, over ninety percent of plantlets survived.

\section{Literature Cited}

Abbès, C., L.E. Parent, and A. Karam. 1995. Effect of $\mathrm{NH}_{4}^{+}: \mathrm{NO}_{3}{ }^{-}$ratios on growth and nitrogen uptake by onions. Plant Soil 171:289-296

Acuña Chinchila, P. 1993. Micropropagation of banana from vegetative shoot tips. CorbanaRevista 17(39):9-12

Alvard, D., F. Côte, and C. Teisson. 1993. Comparison of methods of liquid medium culture for banana micropropagation: Effects of temporary immersion of explants. Plant Cell Tiss. Org. Cult. 32:55-60

Arinaitwe, G., P.R. Rubaihayo, and M.J.S. Magambo. 2000. Proliferation rate effects of cytokinins on bananas (Musa spp.) cultivars. Sci. Hort. $86: 13-21$

Bekheet, S.A. and M.M. Saker. 1999. Rapid mass micropropagation of banana. Bul. Nat. Res. C. 24(2):221-231

Berg, L.A. and M. Bustamante. 1974. Heat treatment and meristem culture for the production of virusfree bananas. Phytopathology 64:320-322

Bower, J.P. and C. Fraser. 1982. Shoot tip culture of Williams bananas. Subtropica 3:13-16

Cronauer, S.S. and A.D. Krikorian. 1984. Rapid multiplication of bananas and plantains by in vitro shoot tip culture. HortScience 19(2):234-235

Dhumale, D.B., A.R. Kadu, S.R. Gholar, and G.L. Ingole. 1997. In vitro multiplication of banana var. 'Shrimanti' from the shoot tip explants. Ann. Plant Physiol. 11(2):214-218

Dore Swamy, R., N.K. Srinivasa Rao, and E.K. Chacko. 1983. Tissue-culture propagation of banana. Sci. Hort. 18:247-252

Fasolo, F., R.H. Zimmerman, and I. Fordham. 1989. Adventitious shoot formation on excised leaves of in vitro grown shoots of apple cultivars. Plant Cell Tiss. Org. Cult. 16:75-87

Hwang, S.C., C.L. Chen, and H.L. Lin. 1984. Cultivation of banana using plantlets from meristem culture. Hort. Sci. 19:231-233

Leblay, C., E. Chevreau, and L.M. Raboin. 1991. Adventitious shoot regeneration from in vitro leaves of several pear cultivars (Pyrus communis L.). Plant Cell Tiss. Org. Cult. 25:99-105

Li, B. and Z.H. Han. 2003. Influence of nitrogen ratio and carbon sources on adventitious shoots regeneration of Malus zumi leaves in vitro. J. Agr. Biotechnol. 11(3):253:258
Lin, C.H., W.Y. Xu, X.H. Wu, and S.S. Zhang. 2004. Technical standards for the production of disease-free tissue cultured banana plantlets. FuJian Fruits (1):43-46

Marchal, J., C. Teisson, J.V. Escalant, and L.C. Navarro-Mastache. 1988. Echanges d'éléments minéraux et carbonés en culture in vitro: cas du bananier. Fruits 43(9):485-490

Ma, S.S. and C.R. Shii. 1972. In vitro formation of adventitious buds in banana shoot apex following decapitation. J. Chinese Soc. Hort. Sci. 18:135-142

Ma, S.S. and C.R. Shii. 1974. Growing banana plantlets from adventitious buds. J. Chinese Soc. Hort. Sci. 20:6-12

Matsumoto, K. and A.K.C. Brandão. 2002. Comparison of temporary and permanent immersion system for the in vitro culture of banana. InfoMusa 11(2):36-37

Murashige, T. and F. Skoog. 1962.Arevised medium for rapid growth and bioassays with tobacco tissue cultures. Physiol. Plant 15:473-497

Samuel, D.K., K.S. Mohan, K. Jagdish Chandra, and L. Sahijram. 1999. Detection of banana bunchy top virus in micropropagated plants by a PCR-generated DNA probe. Pest Mgt. Hort. Ecos. 5(1):32-37

Vinh, D.N., L.H. Ham, and N.B. Phu. 1997. Study for improving banana multiplication rate in vitro. Agric. Food Ind. 12(11):518-520

Vuylsteke, D. and R. Ortiz. 1996. Field performance of conventional vs. in vitro propagules of plantain (Musa spp., AAB Group). Hort. Sci. 31:962-865

Wang, C.H., Z.R. Ma, W. Liu, K.L. Wu, Y.Q. Zhang, and D.H.Ling. 2001. Optimization for direct budding from explants in banana using orthogonal design. J. Trop. Subtrop. Bot. 9(1):69-74

Wang L.J., Y.L. Liu, K. Ma, X.N. Liu, and J.Z Wang. 1997. Effects of autoclaving on the $\mathrm{pH}$ values of MS cultural medium. Plant Physiol. Commun. 33(1):10-14

Wong, W.C. 1986. In vitro propagation of banana (Musa spp.): Initiation, proliferation and development of shoot-tip cultures on defined media. Plant Cell Tiss. Org. Cult. 6:159-166 